\title{
Miłość większa niż śmierć w doświadczeniu mistycznym św. siostry Faustyny
}

Przypadająca w 2018 roku 80. rocznica śmierci siostry Faustyny Kowalskiej, polskiej świętej, apostołki Bożego miłosierdzia, inspiruje i zachęca do pogłębionej analizy duchowej spuścizny, zapisanej szczególnie w Dzienniczku².

Siostra Faustyna, która w ukryciu klasztoru uczyniła ze swego życia hymn na cześć Bożego miłosierdzia, stała się przewodniczką i mistrzynią na drogach życia duchowego ${ }^{3}$. Jej osoba i doktryna są nadal aktualne i stanowią bogate źródło wiedzy teologicznej o tajemnicy Boga bogatego w miłosierdzi e , a doświadczenie mistyczne apostołki Bożego miłosierdzia może być wzorem nie tylko w poznawaniu miłosiernej miłości Boga, ale również w odkrywaniu sensu i ostatecznego

1 S. M. Nulla Chmura ZMBM - absolwentka teologii Uniwersytetu Stefana Kardynała Wyszyńskiego w Warszawie, ukończyła dziennikarstwo podyplomowe na Uniwersytecie Śląskim, animuje wspólnotę Apostołów Bożego Miłosierdzia Faustinum, prowadzi prelekcje o Bożym miłosierdziu i św. siostrze Faustynie. E-mail: faustyna@faustyna.pl.

2 Faustyna Kowalska, Dzienniczek. Miłosierdzie Boże w duszy mojej, Kraków 2014 [dalej: Dz.]. Por. Listy świętej Siostry Faustyny, oprac. B. Piekut, Kraków 2005.

3 Por. Jan Paweł II, Dar Boży dla naszych czasów. Homilia w czasie Mszy Świętej kanonizacyjnej bt. s. Faustyny Kowalskiej w dniu 30 kwietnia 2000 r., „L'Osservatore Romano” wyd. pol. (nr 6) 2000, s. 25-26.

4 Por. Jan Paweł II, Encyklika Dives in Misericordia, 77-139. 
celu życia człowieka, życia i umierania oraz nadziei życia wiecznego ${ }^{5}$. Rzeczywistość śmierci zawsze budziła lęk, a w obecnej dobie ta tematyka bywa na różne sposoby eliminowana z myślenia współczesnego człowieka. Świadectwo siostry Faustyny rzuca jasny promień światła na ten ważny wymiar ludzkiej egzystencji i ukazuje to zagadnienie z perspektywy spotkania z odwieczną Miłością.

Święty Jan Paweł II, który beatyfikował i kanonizował siostrę Faustynę, ukazał światu jej drogę duchową, po której Bóg pragnie obecnie prowadzić ludzi ${ }^{6}$. W homilii kanonizacyjnej powiedział: „Doznaję dziś naprawdę wielkiej radości, ukazując całemu Kościołowi jako dar Boży dla naszych czasów życie i świadectwo Siostry Faustyny Kowalskiej. [...] Chrystusowe orędzie dociera do nas w geście Jego rąk wyciągniętych ku cierpiącemu człowiekowi. Takiego właśnie widziała Go i takiego ogłosiła ludziom wszystkich kontynentów Siostra Faustyna". Dalej ojciec święty dodał, że poprzez tę kanonizację przekazuje nowemu tysiącleciu orędzie miłosierdzia, aby wszyscy ludzie uczyli się poznawać prawdziwe oblicze Boga i prawdziwe oblicze człowieka ${ }^{7}$. Ojciec święty podkreślił wówczas doniosłość otrzymanego przez siostrę Faustynę przesłania oraz uniwersalny wymiar jej misji i duchowości.

Niniejszy artykuł stanowi próbę przedstawienia zjawiska umierania i śmierci w doświadczeniu mistycznym apostołki Bożego miłosierdzia, a także nadziei na życie wieczne. W pierwszej części przedstawione zostanie doświadczenie umierania w życiu siostry Faustyny i cały realizm śmierci, a także tęsknota za Bogiem i pragnienie śmierci. W następnej części, podkreślając wielką wagę zawierzenia Miłosiernej Miłości, ukażę misterium śmierci jako spotkanie z miłosiernym Bogiem; spotkanie to zapoczątkowuje Eucharystia, a godzina śmierci jest okazją do uwielbienia Bożego miłosierdzia. Dla siostry Faustyny w życiu i śmierci liczyła się tylko miłość, która jest potężniejsza niż śmierć, o czym będzie mowa

5 Nadprzyrodzone dary, które otrzymała św. Faustyna, a także jej nadzwyczajne doświadczenia, zostały opisane w książce: S. Urbański, Mistyczny świat ducha [Kanonizacja s. Faustyny Kowalskiej], Warszawa 2000.

${ }_{6}^{6}$ Beatyfikacja odbyła się 18 kwietnia 1993 roku, a kanonizacja 30 kwietnia 2000 rou w Rzymie na placu św. Piotra.

Por. Jan Paweł II, Dar Boży dla naszych czasów, dz. cyt., s. 26. 
w ostatnim punkcie. Śmierć jako Boży posłaniec otwiera bramę nieba, będącego ostatecznym celem jej życia.

Podjęty temat jest szeroki, a skromne ramy artykułu nie pozwalają rozwinąć wszystkich wątków wspomnianego zagadnienia. Podstawowe źródło badawcze tego zagadnienia stanowi Dzienniczek św. siostry Faustyny.

\section{Doświadczenie umierania i śmierci w życiu siostry Faustyny}

Święty Jan Paweł II dostrzegł, że dziedzictwo duchowe pozostawione przez siostrę Faustynę ma wielkie znaczenie jako opór przeciw złu działającemu w świecie, przeciw złu, w które uwikłani są człowiek i świat. Chrystus za pośrednictwem siostry Faustyny mówi: „Zło nie odnosi ostatecznego zwycięstwa! Tajemnica paschalna potwierdza, że ostatecznie zwycięskie jest dobro, że życie odnosi zwycięstwo nad śmiercią, a nad nienawiścią tryumfuje miłość"8.

Tylko Boże miłosierdzie oświeca tajemnicę człowieka. Prawdę tę wyraził również Benedykt XVI po nawiedzeniu Sanktuarium Bożego Miłosierdzia w Krakowie w 2006 roku: „W klasztorze w pobliżu tego sanktuarium, rozważając świetlane rany zmartwychwstałego Chrystusa, siostra Faustyna Kowalska otrzymała orędzie ufności dla ludzkości, orędzie Miłosierdzia Bożego, którego echem i interpretatorem stał się Jan Paweł II, i które jest rzeczywiście głównym przesłaniem dla naszych czasów: Miłosierdzie jako siła Boga, jako Boża granica dla zła świata"9.

8 Jan Paweł II, Tajemnica miłosierdzia, w: Jan Paweł II, Pamięć i tożsamość. Rozmowy na przełomie tysiącleci, Kraków 2005, s. 62.

9 Benedykt XVI, O przeżyciach $w$ Polsce, Audiencja środowa 31.05.2006, http://info.wiara.pl/doc/159412.Audiencja-srodowa-Benedykt-o-przezyciach-w-Polsce/3. Również Papież Franciszek w bulli Misericordiae Vultus wspomina św. siostrę Faustynę Kowalską i nazywa ją „wielką apostołką miłosierdzia”. „Ta, która została wezwana do wejścia w głębokości Bożego miłosierdzia, niech wstawia się za nami i uzyska dla nas łaskę życia i chodzenia zawsze w świetle Bożego przebaczenia oraz niezachwianej ufności w Jego miłość" - por. Franciszek, bulla Misericordiae vultus, 24. Por. Franciszek, Miłosierdzie to imię Boga, Kraków 2016. Metropolita krakowski kard. S. Dziwisz w homilii na rozpoczęcie Światowych Dni Młodzieży 26 lipca 2016 roku na krakowskich Błoniach powiedział m.in.: „Moi drodzy, 
Największym złem dla człowieka są grzech i śmierć oraz cierpienia z tym związane ${ }^{10}$. Siostra Faustyna na kartach Dzienniczka wielokrotnie pisze o zjawisku śmierci i umierania, i chociaż nie wypowiada konkretnej doktryny, to ukazuje to zagadnienie od strony przeżyciowej, jako jej osobiste doświadczenie ${ }^{11}$. Ukazuje swój stosunek do własnej śmierci, osobiste przygotowanie się do niej, pisze o trudnościach i niepokoju, jaki przeżywała na myśl o śmierci, dzieli się także doświadczeniem z pogranicza życia i śmierci, opisuje przeżycia związane $\mathrm{z}$ wezwaniem na sąd Boży ${ }^{12}$.

\section{1. Życie bolesnym umieraniem}

Orędzie o Bożym miłosierdziu przekazane Kościołowi i światu przez Siostrę Faustynę niesie wszystkim ludziom nadzieję zwycięstwa nad złem, które jest udziałem człowieka, zwłaszcza nadzieję na ostateczne zwycięstwo w godzinę śmierci. Zwycięstwo to zapewnia Chrystus wszystkim tym, którzy uwielbiają Boże miłosierdzie ${ }^{13}$.

Kraków żyje tajemnicą Bożego Miłosierdzia również dzięki pokornej Siostrze Faustynie, która uwrażliwiła Kościół i świat na ten szczególny rys Boga" - por. Homilia kard. Stanisława Dziwisza, w: Błogosławieni miłosierni, albowiem oni miłosierdzia dostapią. Papież Franciszek w Polsce. 27-31 lipca 2016 r., Marki 2016, s. 14.

10 Por. Jan Paweł II, list Salvifici doloris; por. Jan Paweł II, adhort. apost. Reconciliatio et paenitentia; por. H. Sławiński, Ambiwalentne postawy człowieka wobec cierpienia, „Studia Włocławskie" 10 (2007), s. 213-220.

11 Por. Dz. 561, 723.

12 Por. Dz., 36.

13 Por. I. Różycki, Nabożeństwo do Miłosierdzia Bożego. Studium teologiczne "Dzienniczka" bł. s. Faustyny Kowalskiej na temat Nabożeństwa, Kraków 1999, s. 95-118 (gdzie wyliczono pięć form nabożeństwa do miłosierdzia Bożego: kult obrazu Jezusa Miłosiernego, Święto Miłosierdzia Bożego, koronka do Bożego miłosierdzia, szerzenie czci Bożego miłosierdzia, godzina miłosierdzia). Do każdej z tych form przywiązane są niezwykłe obietnice Boże otrzymania wielkich łask w życiu, a szczególnie w godzinie śmierci; Dz. 47-48: „Wymaluj obraz według rysunku, który widzisz, z podpisem:Jezu, ufam Tobie. Pragnę, aby ten obraz czczono najpierw w kaplicy waszej i na całym świecie. Obiecuję, że dusza, która czcić będzie ten obraz, nie zginie. Obiecuję także, już tu na ziemi, zwycięstwo nad nieprzyjaciółmi, a szczególnie w godzinę śmierci. Ja sam bronić ją będę jako swej chwały". Por. Dz. 300, 699, 687, 1541, 1320, 1572, 1540, 1075. Por. E. Siepak, Nowe „Zgromadzenie” Siostry Faustyny. Apostolski Ruch Bożego Miłosierdzia, Kraków 2002. 
Siostra Faustyna żyła na ziemi 33 lata, z tego 13 lat w Zgromadzeniu Sióstr Matki Bożej Miłosierdzia ${ }^{14}$. Jej krótkie życie obfitowało w różnorakie cierpienia, które jako osoba wrażliwa dotkliwie przeżywała. Cierpienia dotykały ją samą, a także bliskich, z którymi była związana ${ }^{15}$. Nasiliły się znacznie, gdy zachorowała na gruźlicę. „Niedomagania fizyczne były szkołą cierpliwości dla mnie. Jezus tylko wie, ile wysiłków woli musiałam zrobić, żeby spełnić obowiązek" - napisała w Dzienniczku ${ }^{16}$. Na drodze jej życia cierpienie wyrastało jakby wprost spod ziemi ${ }^{17}$.

Będąc w szkole Ukrzyżowanego Mistrza, wiedziała, że miłość mierzona jest cierpieniem i że jedna jest cena, za którą „kupuje się dusze”18. Sam Boski Mistrz pouczał ją o wartości cierpienia: „I powiedział mi Pan: Dziecię Moje, najwięcej Mi się podobasz przez cierpienie. W cierpieniach swoich fizycznych czy też moralnych nie szukaj współczucia u stworzeń. Chcę, aby woń cierpień twoich była czysta, bez żadnych przymieszek. Żądam, żebyś się nie tylko oderwała od stworzeń, ale i sama od siebie. Córko Moja, chcę się napawać miłością serca twego - miłością czystą, dziewiczą, nieskalaną, bez żadnego przyćmienia. Im więcej ukochasz cierpienie, tym miłość twoja ku Mnie będzie czystsza"19. W styczniu 1934 roku zanotowała, że od chwili, w której ukochała cierpienie, przestało jej być cierpieniem ${ }^{20}$.

W Wielki Czwartek 1934 roku na wyraźne życzenie Chrystusa złożyła siebie w ofierze za grzeszników, zwłaszcza za tych, którzy utracili

14 Siostra Faustyna, Helena Kowalska (1925-1938) urodziła się w wielodzietnej rodzinie chłopskiej, żyjącej w skromnych warunkach materialnych. Do szkoły chodziła trzy lata, a mając 16 lat, zaczęła pracować jako służąca, by ulżyć rodzicom. Mając 20 lat, wstąpiła do Zgromadzenia Sióstr Matki Bożej Miłosierdzia w Warszawie, w którym przeżyła 13 lat. Zmarła na gruźlicę, mając 33 lata, w klasztorze w Krakowie-Łagiewnikach. Beatyfikowana (1993) i kanonizowana (2000) przez św. Jana Pawła II. Jej relikwie znajdują się w Sanktuarium Bożego Miłosierdzia w Krakowie-Łagiewnikach. Por. J. Miczyński, Fundament duchowości i charyzmat Zgromadzenia Sióstr Matki Bożej Miłosierdzia, Lublin 2016, s. 251-286. Por. J. Andrasz, Życiorys świętej Faustyny, Kraków 2015.

15 Por. W. Rebeta, Misterium cierpienia św. Faustyny, Lublin, 2014.

16 Dz. 37.

17 Por. Dz. $138,149$.

18 Por. Dz. 342, 324.

19 Dz. 279.

20 Por. Dz. 276. 
nadzieję w miłosierdzie Boż $\mathrm{e}^{21}$. W akcie ofiarowania pisała m.in. „Ofiara ta polega na tym, że przyjmuję z zupełnym poddaniem się woli Bożej wszystkie cierpienia i lęki, i trwogi, jakimi są napełnieni grzesznicy, a w zamian oddaję im wszystkie, jakie mam, pociechy w duszy, które płyną z obcowania z Bogiem"22.

Kilka miesięcy później, w sierpniu, nagle zasłabła i wydawało się jej, że umiera. Tak to opisała: „Nagle zrobiło mi się niedobrze, brak tchu, ciemno w oczach, czuję zamieranie w członkach - to duszenie jest straszne. Chwilka takiego duszenia jest niezmiernie długa... Także przychodzi lęk dziwny pomimo ufności. Pragnęłam przyjąć ostatnie sakramenty święte, jednak spowiedź święta przychodzi bardzo trudno, pomimo pragnienia spowiadania się. Człowiek nie wie, co mówi; jedno zacznie, drugiego nie kończy. O, niech Bóg zachowa każdą duszę od tego odkładania spowiedzi na ostatnią godzinę. Poznałam wielką moc słów kapłana, jaka spływa na duszę chorego. Kiedy się zapytałam ojca duchownego: czy jestem gotowa stanąć przed Bogiem i czy mogę być spokojna - otrzymałam odpowiedź: Możesz być zupełnie spokojna, nie tylko teraz, ale po każdej spowiedzi tygodniowej. Łaska Boża, jaka towarzyszy tym słowom kapłańskim, jest wielka. Dusza odczuwa moc i odwagę do walki"23.

Cierpienia swoje łączyła z cierpieniami Jezusa i ofiarowała za siebie i za nawrócenie ludzi, którzy nie dowierzają dobroci Bożej ${ }^{24}$. Następnego dnia po komunii świętej powiedziała: „Jezu, myślałam, że mnie zabierzesz. A Jezus mi odpowiedział:Jeszcze się nie spełniła wola Moja w tobie całkowicie, jeszcze pozostaniesz na ziemi, ale niedługi czas"25. Po tym wydarzeniu stwierdziła, że straszna jest śmierć, chociaż daje nam życie wieczne ${ }^{26}$.

Pogarszający się stan zdrowia siostry Faustyny sprawiał, że często doświadczała cierpień jakby z pogranicza życia i śmierci. Na dwa lata przed śmiercią napisała: „Życie jest śmiercią ustawiczną, bolesną i straszną,

\footnotetext{
21 Por. Dz. 308.

22 Dz. 309.

23 Dz. 321. Por. Dz. 696.

24 Por. Dz. 323.

25 Por. Dz. 324.

26 Por. Dz. 321
} 
a zarazem jest głębią prawdziwego życia i szczęścia niepojętego, i mocą ducha, a przez to dusza jest zdolna do wielkich czynów dla Boga"27.

Siostra Faustyna opisała także przeżycia związane $\mathrm{z}$ wezwaniem na sąd Boży. „Stanęłam przed Panem sam na sam. Jezus był takim, jakim jest w męce". Wówczas zobaczyła stan swojej duszy i to, co się Bogu nie podoba. „Co to za moment! Kto go opisze? Stanąć naprzeciw trzykroć Świętemu. Zapytał mię Jezus: Kto ty jesteś? Odpowiedziałam: Ja jestem sługą Twoją, Panie. Jesteś winna jednego dnia ognia czyśćcowego. [...] Co chcesz, czy teraz cierpieć jeden dzień, czy przez krótki czas na ziemi?" Odpowiedziała, że chcę cierpieć w czyśćcu i na ziemi nawet do końca świata. „Jezus rzekł: Wystarczy jedno. Zejdziesz na ziemię i cierpieć będziesz wiele, ale niedługo, i spełnisz wolę Moją i życzenia Moje [...]. Wiedz o tym, że wiele, wiele cierpieć będziesz, ale niech cię to nie przeraża, Ja jestem z tobą"28.

Miłość, jaką siostra Faustyna darzyła Boga i ludzi, dawała jej moc do znoszenia cierpień, także tych związanych z tajemnicą umierania. Swoją modlitwą towarzyszyła też innym osobom, które stanęły na krawędzi życia. Wypraszała łaskę ufności konającym, zwłaszcza tym, którzy umierali niepojednani z Bogiem. Sama dokładała wszelkich starań, by jak najlepiej przygotować się do tego decydującego momentu w jej życiu, jakim jest przejście z ziemi do wieczności ${ }^{29}$.

\subsection{Osobiste przygotowanie siostry Faustyny do śmierci}

Siostra Faustyna jasno widziała ostateczny cel swego życia, o czym tak pisze: „Wiem, na co jestem stworzona; wszystkie stworzenia razem nie zastąpią mi Stwórcy; wiem, że moim ostatecznym celem jest Bóg, a więc we wszystkich poczynaniach swoich Boga mam na względzie"30.

Ze wszystkich sił zabiegała o to, by jak najlepiej przygotować się na spotkanie $\mathrm{z}$ Bogiem $\mathrm{w}$ chwili śmierci. W tej intencji modliła się,

\footnotetext{
Dz. 856.

Dz. 36.

Por. Dz. 207, 985, 810, 1536, 1551.

Dz. 1329. Por. Jan Paweł II, List Do moich Braci i Sióstr - ludzi w podeszłym wieku, 14.
} 
odprawiała rozmyślania i starała się, by wszystko, co czyniła, nosiło „cechę celu ostatecznego”. W październiku 1937 roku odprawiała rekolekcje w Krakowie, podczas których w medytacji o śmierci przygotowała się jak na rzeczywistą śmierć; zrobiła rachunek sumienia i „przetrząsnęła” wszystkie sprawy swoje w obliczu śmierci. Uradowała się bardzo, gdy zauważyła, że dzięki łasce Bożej jej czyny miały cechę celu ostatecznego. Postanowiła na przyszłość służyć Bogu z jeszcze większą wiernością. Zanotowała: „Z rana przygotowałam się do przyjęcia Komunii świętej jakoby w życiu moim ostatniej i po Komunii świętej wyobraziłam sobie rzeczywistą śmierć i zmówiłam modlitwy za konających, a później za swoją duszę Z głębokości, i wpuszczono ciało moje do grobu"31.

Starała się o jak największą czystość serca, przepraszała za najmniejsze uchybienia, czyniła postanowienia poprawy, by dochować wierności Bogu na drodze swego powołania ${ }^{32}$. Często korzystała z sakramentu pokuty, w którym dokonują się „największe cuda”33. Zapisała też wzruszające słowa Jezusa: „Wzruszyło się serce Moje miłosierdziem wielkim ku tobie - dziecię Moje najdroższe - kiedy cię ujrzałem w strzępy poszarpaną od wielkiej boleści, którą cierpiałaś, żałując za grzechy swoje. Oto widzę twoją miłość tak czystą i szczerą, że daję ci pierwszeństwo między dziewicami, tyś zaszczytem i chwałą męki Mojej. Każde uniżenie duszy twojej widzę i nic nie uchodzi uwagi Mojej. Pokornych wywyższam aż do tronu swego, bo tak chcę" ${ }^{34}$.

Pragnęła poznać godzinę swej śmierci, o co kilkakrotnie pytała Chrystusa, który początkowo nie ujawniał tej tajemnicy: w sierpniu 1934 roku, gdy doświadczyła cierpień konania, rzekła do Jezusa, że myślała, że ją zabierze. W odpowiedzi usłyszała: „Jeszcze pozostaniesz na ziemi, ale niedługi czas. Podoba Mi się bardzo ufność twoja, ale miłość niech będzie gorętsza. Miłość czysta daje duszy moc w samym konaniu. Kiedy konałem na krzyżu, nie myślałem o sobie, ale o biednych grzesznikach

\footnotetext{
31 Por. Dz. 1343, 1435, 1551.

32 Por. Dz. 42, 329.

33 Por. Dz. 1448, 854.

34 Dz. 282.
} 
i modliłem się do Ojca za nimi. Chcę, ażeby i ostatnie chwile twoje były zupełnie podobne do Mnie na krzyżu" ${ }^{35}$.

W styczniu 1938 roku zadała Chrystusowi podobne pytanie: „Kiedy mnie zabierzesz do siebie? Ja już się tak źle czułam i z takim utęsknieniem czekałam na przyjście Twoje”. W odpowiedzi usłyszała: „Bądź zawsze gotowa, ale już niedługo cię pozostawię na tym wygnaniu; musi się spełnić w tobie Moja święta wola”. Siostra Faustyna dodała: „O mój Jezu, dziwi mnie tylko to, że Ty dajesz mi poznać tyle tajemnic, a tej tajemnicy, to jest godziny śmierci mojej, nie chcesz mi powiedzieć. - I odpowiedział mi Pan: Bądź spokojna, dam ci ją poznać, lecz jeszcze nie teraz"”36.

Jako wierna uczennica Mistrza czyniła wszystko, by Jego pouczenia realizować w życiu, czego przykładem może być następujący zapis uczyniony w kwietniu 1938 roku: „Niedziela Przewodnia. Dziś ofiarowałam się Panu powtórnie jako całopalna ofiara za grzeszników. Jezu mój, jeżeli już się zbliża koniec mojego życia, błagam Cię najpokorniej, przyjmij śmierć moją w zjednoczeniu z Tobą jako ofiarę całopalną, którą Ci dziś w przytomności umysłu i z całą świadomością woli składam w potrójnym celu: pierwsze - aby dzieło miłosierdzia Twego rozeszło się na świat cały i aby święto Miłosierdzia Bożego zostało uroczyście zatwierdzone i obchodzone; drugie - aby grzesznicy uciekali się do miłosierdzia Twego, doznając niewysłowionych skutków tego miłosierdzia, a szczególnie dusze konające; trzecie - aby całość dzieła miłosierdzia Twego była wykonana według życzeń Twoich [...]. Przyjmij, najlitościwszy Jezu, tę nieudolną ofiarę moją, którą Ci dziś złożyłam wobec nieba i ziemi. Niech Twoje Najświętsze Serce, pełne miłosierdzia, uzupełni, co mi w niej nie dostawa, i ofiaruje Ojcu swemu za nawrócenie grzeszników. Pragnę dusz, o Chryste" ${ }^{37}$.

Wiedziała, że w tej ostatniej godzinie liczyć może jedynie na miłosierdzie Boże, a nie na swoje zasługi. Dlatego przez całe życie zanurzała się

35 Dz. 324.

36 Dz. 1539. W maju 1936 roku s. Faustyna, wyjeżdżając z Derd do Krakowa, przy pożegnaniu powiedziała s. Justynie Gołofit, że za dwa lata na jesieni umrze. Por. Wspomnienia o świętej Faustynie Kowalskiej ze Zgromadzenia Matki Bożej Miłosierdzia, Kraków 2013, s. 179.

37 Dz. 1680. 
w „otchłani miłosierdzia”, która jest otwarta dla każdego ${ }^{38}$. Oddawała w opiekę Matce Bożej całe swoje życie, a szczególnie godzinę śmierci: „O Maryjo, Niepokalana Dziewico, czysty krysztale dla serca mojego, Tyś mocy moja, o silna kotwico, Tyś tarczą i obroną dla serca słabego. [...] O Maryjo, słodka Matko moja, oddaję Ci duszę, ciało i biedne me serce, bądź strażniczką życia mego, a szczególnie w śmierci godzinie, w ostatniej walce" 39 .

Dziękowała Bogu za wszystko, także za godzinę śmierci, „za cierpienia wewnętrzne, za oschłości ducha, za trwogi, lęki i niepewności, za ciemność i gęsty mrok wewnętrzny, za pokusy i różne doświadczenia, za udręki, które wypowiedzieć trudno, a zwłaszcza za te, w których nas nikt nie zrozumie, za godzinę śmierci, za ciężkość walki w niej, za całą jej gorycz ${ }^{40}$. Cieszyła się, że kruszeje ,jej ziemska powłoka”, bo był to dla niej znak, że niebawem znajdzie się w domu Ojca ${ }^{41}$.

Tęsknota za Bogiem i pragnienie śmierci były u siostry Faustyny tak wielkie, że w czerwcu 1938 roku, gdy czuła się bardzo słaba i myślała, że umrze, powiedziała: „Zwodzisz mnie, Jezu, ukazujesz mi bramę otwartą nieba i znowu pozostawiasz mnie na ziemi" ${ }^{42}$.

\subsection{Tęsknota za Bogiem, pragnienie śmierci}

Siostra Faustyna z coraz większym utęsknieniem oczekiwała spotkania z Bogiem w chwili śmierci. Ta tęsknota była niekiedy tak wielka, że sama dziwiła się, że nie spowoduje to rozłączenia duszy od ciała, tak bardzo pragnęła „zatonąć” w Bogu. Życie na ziemi nazywała „strasznym wygnaniem”, wzywała mieszkańców niebios, by wejrzeli na nią jako na „wygnankę". Doświadczając nadzwyczajnych mistycznych łask, wiedziała, jak „cieniutka zasłona dzieli ją od Pana”, ona jednak pragnie oglądać

\footnotetext{
Por. Dz. 1553.

Dz. 161.

Por. Dz. 343.

Por. Dz. 1616.

Dz. 1786-1787.
} 
Boga bez zasłon, twarzą w twarz. Zaraz jednak dodawała, by wszystko stało się według woli Boga ${ }^{43}$.

Wiedziała, że w tej tęsknocie za Stwórcą tylko On ją rozumie, a wszystko, co jest na ziemi, wydawało jej się bladym cieniem wobec wspaniałości Boga. Uznawała, że Bóg uczynił dla niej „niepojęcie wiele”, bo sam w sposób szczególny ją odwiedzał, jednak te odwiedziny nie koiły jej zranionego serca, ale pobudzały do coraz większej tęsknoty za Bogiem. „O, weź mnie do siebie, Panie, jeżeli jest taka wola Twoja. Ty wiesz, że umieram i umieram z tęsknoty za Tobą, a umrzeć nie mogę"

Umierała z pragnienia, by połączyć się na wieki ze Stwórcą, i czyniła „wyrzuty” Bogu, że nie pozwala śmierci zbliżyć się do niej ${ }^{45}$. W grudniu 1936 roku opanowała siostrę Faustynę tak wielka tęsknota za Bogiem, że przycisnęła do serca broszurkę z obrazem Jezusa Miłosiernego i powiedziała: „Jezu, Miłości wiekuista, dla Ciebie żyję, dla Ciebie umieram i z Tobą połączyć się pragnę”. Wówczas ujrzała Pana „w niepojętej piękności”, który spojrzał na nią łaskawie i powiedział: „Córko Moja, i Ja z miłości ku tobie zstąpiłem z nieba, dla ciebie żyłem, dla ciebie umarłem i dla ciebie stworzyłem niebiosa”. Siostra Faustyna zapisała: „I przytulił mnie Jezus do swego Serca i rzekł mi:Już niedługo, bądź spokojna, córko Moja"46.

To doświadczenie miłości Bożej na nowo zapaliło serce siostry Faustyny do cierpień, aż do chwili, w której Bóg powie: dosyć. I gotowa była żyć na ziemi nawet „tysiąc lat”, bo pojęła, że w świetle Bożym jest to tylko jedna chwila ${ }^{47}$.

Siostra Faustyna odczuwała niechęć i odrazę do wszystkiego, co ją otaczało. Wszystko wydawało jej się blade, pragnęła tylko Boga samego, a jednak musiała żyć. Ten stan ducha nazywała „męczeństwem nie do opisania”. Sama wyjaśniła powody tej udręki: „Bóg udziela się duszy w sposób miłosny i pociąga ją w swe głębie niepojęte Bóstwa, ale zarazem pozostawia ją tu na ziemi, na to jedynie, aby cierpieć i konać w tęsknocie za Nim. A ta silna miłość jest tak czysta, że sam Bóg ma w niej swe

\footnotetext{
Por. Dz. 807.

Dz. 841.

Por. Dz. 952.

Dz. 853.

47 Por. Dz. 853.
} 
upodobanie, a do uczynków jej miłość własna nie ma przystępu, bo tu jest wszystko przepełnione goryczą na wskroś, a więc i na wskroś czyste"48.

W tej udręce pocieszał ją sam Chrystus, który mówił, że gdy w niebie ujrzy swoje obecne dni, rozraduje się i będzie chciała widzieć ich jak najwięcej; podkreślał zarazem, że podoba $\mathrm{Mu}$ się jej czujność. Siostra Faustyna z miłością poddawała się woli Bożej i jej „miłościwym wyrokom" ${ }^{49}$. Z jednej strony pragnęła być uwolniona od ciała, jednak z drugiej strony we wszystkich pragnieniach swoich poddawała się woli Stwórcy i sama z siebie nie chciałaby umrzeć nawet o minutę wcześniej ani też żyć o minutę dłużej; nie chciała ani zmniejszenia cierpień, ani ich powiększania, ale we wszystkim tym pragnęła wypełnić wolę Stwórcy. „Choć zapały moje wielkie i pragnienia moje wielkie palą się w sercu moim, jednak nigdy ponad wolę Twoją ${ }^{50}$.

\section{Spotkanie z miłosiernym Panem w godzinie śmierci}

Siostra Faustyna jako powiernica Chrystusa Miłosiernego poznała tajemnicę bezgranicznej miłości Boga do człowieka, a zarazem nędzę człowieka. Boski Mistrz pouczał ją, że pomiędzy Nim a nią jest przepaść bezdenna, która dzieli Stwórcę od stworzenia; tę przepaść wyrównuje miłosierdzie Boże, które „pracuje” we wszystkich sercach. Zarówno grzesznicy, jak i sprawiedliwi potrzebują Bożego miłosierdzia, a nawrócenie i wytrwanie jest łaską Bożą ${ }^{51}$.

„Zmartwychwstanę w Jezusie, ale muszę wpierw w Nim żyć" - zanotowała ${ }^{52}$. Wiedziała, że droga do zjednoczenia z Bogiem prowadzi przez sakramenty Kościoła, że to życie z Bogiem musi rozpocząć się tu na ziemi. „Pragnę wysławiać nieskończone miłosierdzie Twoje w życiu, w godzinie śmierci i w zmartwychwstaniu, i w nieskończoność" ${ }^{3}$.

\footnotetext{
$48 \quad$ Dz. 856.

49 Por. Dz. 1787.

50 Por. Dz. 1729.

51 Por. Dz. 1576, 1577.

52 Dz. 392.

53 Dz. 697.
} 
Uwielbiała miłosierdzie Boże, w którym dostrzegała źródło swej siły, pokoju i odpocznienia; w promieniach miłosierdzia codziennie „kąpała” swoją duszę i była przekonana, że nie zna momentu w życiu, w którym by nie doznawała miłosierdzia Bożego. Na nic też nie liczyła w całym życiu, tylko na tę miłosierną miłość Boga ${ }^{54}$.

W kwietniu 1938 roku, gdy lekarz stwierdził ciężki stan jej zdrowia, dziękowała Bogu za wszystko, co otrzymała w życiu. Napisała: „Czułam tak głęboki spokój, że gdyby śmierć w tej chwili nastąpiła, nie powiedziałabym jej - poczekaj, bo mam jeszcze sprawy do załatwienia. Nie, ale $\mathrm{z}$ radością powitałabym ją, bo jestem gotowa na spotkanie się z Panem" 55 .

Dziękowała Bogu także za sakramenty święte, które były znakami działania Bożego miłosierdzia. Dziękowała zwłaszcza za chrzest święty, który wszczepił ją w rodzinę Bożą, za spowiedź świętą jako „niewyczerpane źródło wielkiego miłosierdzia, krynicę niepojętą”, w której „dusze bieleją grzechem zmazane"; za Komunię Świętą, w której Bóg sam siebie nam daje. Za sakrament bierzmowania i za sakrament namaszczenia chorych, który umacnia nas w ostatniej chwili życia ${ }^{56}$.

W styczniu 1934 roku napisała, że gdy przejęła się wiecznością i jej tajemnicami, zaczęła się lękać, a potem zaczęły ją dręczyć różne niepewności. Wówczas interweniował sam Jezus, mówiąc, by nie lękała się domu Ojca swego, a próżne dociekania zostawiła „mędrcom tego świata" ${ }^{57}$. W cztery lata później Chrystus pouczał siostrę Faustynę: „Zdaj się cała na Mnie w godzinę śmierci, a Ja cię przedstawię Ojcu Mojemu jako oblubienicę swoją. Teraz polecam ci, abyś w szczególny sposób łączyła swoje choćby najdrobniejsze uczynki z zasługami Moimi, a wtenczas Ojciec Mój spojrzy na nie z miłością, jako na Moje"58. I żądał, by siostra Faustyna nadal łączyła się z Nim i by była „dzieckiem” wobec Jego zastępców, przez których rozwiewa wszystkie jej wątpliwości ${ }^{59}$. Boski Mistrz

\footnotetext{
Por. Dz. 697.

Dz. 1679.

Por. Dz. 1286.

Por. Dz. 290.

Dz. 1543.

Por. Dz. 1544.
} 
zapewniał, że jak jest zjednoczona z Nim w życiu, tak też będzie zjednoczona w chwili śmierci ${ }^{60}$.

Jak bardzo siostra Faustyna wyczekiwała spotkania twarzą w twarz z miłosiernym Bogiem w dniu śmierci, świadczy zapis z sierpnia 1937 roku w formie wiersza, w którym dzień swojej śmierci nazywa dniem „wieczystym i upragnionym", który rozwiąże jej zasłony i stanie się zbawieniem; dniem „przepięknym i chwilą niezrównaną”, której wygląda z tęsknotą i upragnieniem; że będzie to dzień, w którym po raz pierwszy ujrzy swego Boga, Oblubieńca i Pana; to dla niej dzień „najuroczystszy, dzień jasności", w którym pozna Boga w Jego potędze i cała zatonie w Jego miłości; to dzień „szczęśliwy i błogosławiony”. To dzień, którego przez całe życie wygląda i wyczekuje na Boga, którego jedynie miłuje ${ }^{61}$. „Tyś mi, o Jezu, w życiu i śmierci zachwytem i czarem. [...] o dniu rozkoszy, wieczystych słodyczy, wielkiego majestatu Boże, Oblubieńcze mój”62.

Siostra Faustyna przez całe życie przygotowywała się do tego „najuroczystszego" dnia w życiu, jakim jest godzina śmierci. Miłością i ufnością pokonała lęk i obawę przed śmiercią. A wszystko to zawdzięczała Komunii Świętej, którą codziennie przyjmowała.

\subsection{Eucharystia nadzieją w życiu i śmierci}

Eucharystia zajmowała centralne miejsce w życiu siostry Faustyny. Do przyjęcia każdej Komunii Świętej starannie się przygotowywała. W tym celu często korzystała z sakramentu pokuty, który oczyszczał jej duszę i otwierał drogę do zjednoczenia z Bogiem w Komunii Świętej ${ }^{63}$. Każdą wolną chwilę spędzała u stóp Jezusa utajonego w Najświętszym Sakramencie, adorowała go, wynagradzając oziębłość innych ${ }^{64}$. W listopadzie 1937 roku wyznała, że wszystko, co w niej jest dobrego, sprawiła Komunia Święta, że jej wszystko zawdzięcza ${ }^{65}$. „Czuję, że ten święty

\footnotetext{
60 Por. Dz. 1552.

61 Por. Dz. 1230.

62 Dz. 1230.

63 Por. Dz. 817; por. Jan Paweł II, adhort. apost. Reconciliatio et paenitentia.

64 Por. Dz. 855, 927.

65 Por. Dz. 1392.
} 
ogień przemienił mnie całkowicie. 0 , jak się cieszę, że jestem mieszkaniem dla Ciebie, Panie; serce moje jest świątynią, w której ustawicznie przebywasz"66.

Uwielbiała Jezusa utajonego w Hostii świętej, nazywając Go „życiem swej duszy” i „chwalebnym zadatkiem zmartwychwstania” ${ }^{67}$. Prosiła Boga, by zanurzał jej duszę w oceanie bóstwa swego i udzielił jej łaski poznania siebie; wiedziała, że im lepiej Go pozna, tym bardziej spotęguje się jej miłość ${ }^{68}$. Komunia Święta dawała jej siłę do cierpień i walki i czyniła ją zdolniejszą do obcowania z Bogiem przez całą wiecznośćc9.

Pragnęła „płonąć” przed majestatem Bożym, jak „żywa hostia” na Bożą cześć, dlatego prosiła, by Jezus przeistoczył ją w drugą hostię. W odpowiedzi usłyszała: „Jesteś żywą hostią, miłą Ojcu niebieskiemu, ale rozmyślaj, czym jest hostia - ofiara"70. Z Komunii Świętej czerpała niezwykłą moc i odwagę do podejmowania wyzwań codzienności i lękała się dnia, w którym by nie mogła jej przyjąć. Dzięki Komunii Świętej „śmiało patrzyła na wszystko, nawet samej śmierci w oczy"71.

Wiedziała, jak wielkie tajemnice dokonują się w czasie mszy świętej i z jak wielką pobożnością powinniśmy brać udział „w tej śmierci Jezusa”. „Poznamy kiedyś, co Bóg czyni dla nas w każdej Mszy świętej i jaki w niej dla nas gotuje dar. Jego Boska miłość tylko na taki dar zdobyć się mogła. O Jezu, Jezu mój, jak wielkim bólem przeniknięta jest dusza moja, widząc tryskający zdrój żywota z taką słodyczą i mocą dla każdej duszy"72.

Adorowała Hostię Świętą, w której dostrzegała testament miłosierdzia Bożego, w której zawarte jest miłosierdzie Ojca, Syna i Ducha Świętego oraz Ciało i Krew Pana Jezusa jako dowód nieskończonego miłosierdzia ku nam; Hostia Święta jako jedyna nadzieja w cierpieniach

\footnotetext{
Dz. 1392; por. V. Flynn, 7 tajemnic Eucharystii, tłum. P. Kopycki, Radom 2011, s. 23.

Por. Dz. 1427.

Por. Dz. 605; por. Jan Paweł II, list apost. O tajemnicy i kulcie Eucharystii, Rzym 1980.

Por. Dz. 1509, 1810.

Dz. 1826.

Por. Dz. 1826, por. Dz. 876.

Dz. 914; por. H. Wejman, Kontemplować Boga w tajemnicy Jego miłosierdzia, Kraków 2006,
} s. 179. 
i przeciwnościach, wśród tęsknoty i bólu, wśród ciemności i burz, jedyna nadzieja w życiu i śmierci godzinie ${ }^{73}$.

W czerwcu 1938 roku siostra Faustyna zanotowała następujące słowa Chrystusa: „Teraz rozważysz o Mojej miłości w Najświętszym Sakramencie. Tu jestem cały dla ciebie, z duszą, ciałem i Bóstwem, jako oblubieniec twój. Ty wiesz, czego żąda miłość - jednej tylko rzeczy, to jest wzajemności" "ㄱ. Siostra Faustyna odpowiadając, napisała, że pragnie kochać Jezusa taką miłością, jaką jeszcze nikt Go dotąd nie kochał. Pragnęła, aby cały świat zamienił się w miłość ku Niemu. „Oblubieńcze mój, Ty mnie karmisz mlekiem i miodem Serca swego; od najwcześniejszych lat wychowywałeś mnie sam dla siebie, abym umiała Cię teraz kochać. Ty wiesz, że Cię miłuję, bo Ty sam tylko znasz głębokość ofiary, którą Ci codziennie składam"75.

Wszystkie bóle i tęsknoty składała u stóp Jezusa utajonego w Najświętszym Sakramencie, cieszyła się, gdy mogła trochę cierpieć dla Boga, a w cierpieniu ponad siły przychodziła do Pana w Najświętszym Sakramencie. Jezusa w Eucharystii nazywała życiem swej duszy, który przez mękę i konanie daje jej życie wieczne. Bez Eucharystii nie umiałaby zmierzyć się z przeciwnościami ani podejmować walki na „śmierć i życie"76.

Sam Chrystus upewniał ją, że siłę do znoszenia cierpień zawdzięcza częstej Komunii Świętej, a łaski z tego źródła miłosierdzia czerpie się naczyniem ufności ${ }^{77}$. Hostię świętą nazywała nadzieją jedyną w życiu i śmierci ${ }^{78}$.

\footnotetext{
Por. Dz. 356.

Dz. 1770.

Dz. 1771.

Por. Dz. 73, 1393, 1654.

Por. Dz. 1487.

Por. Dz. 356.
} 


\subsection{Zawierzenie miłosiernej miłości Boga warunkiem szczęśliwej śmierci}

Siostra Faustyna własnym przykładem uczy podejścia do śmierci, do umierania. Szczęśliwa śmierć to śmierć, która doprowadza człowieka do domu Ojca ${ }^{79}$. Całe życie zabiegała o to, by ten cel osiągnąć. Modliła się o szczęśliwą, dobrą śmierć, która otworzy jej bramy nieba; prosiła o to dla siebie, ale też dla innych ludzi, szczególnie dla konających i tych, którzy nie byli pojednani z Bogiem. Łączyła swoje cierpienia, gorycze i samo konanie $\mathrm{z}$ męką Jezusową i ofiarowywała się za świat, aby uprosić miłosierdzie Boże innym. Ufała Bogu i zdawała się na Jego wolę, „która jest samym miłosierdziem”; na to miłosierdzie liczyła też sama „w tej ostatniej godzinie”. Modliła się: „O Zbawicielu świata, Miłośniku ludzkiego zbawienia, który w tak strasznej boleści katuszy zapomnisz o sobie, a myślisz o dusz zbawieniu, Jezu najlitościwszy, udziel mi łaski zapomnienia o sobie, abym cała żyła dla dusz, pomagając Ci w dziele zbawienia, według najświętszej woli Ojca Twego" ".

Z ufnością zawierzała Jezusowi miłosiernemu, konającemu na krzyżu, swoją godzinę śmierci. Prosiła, by najmiłosierniejsze Serce Jezusa, otwarte włócznią, ukryło ją w ostatniej godzinie życia. „O Krwi i Wodo, która wytrysłaś z Serca Jezusowego jako zdrój niezgłębionego miłosierdzia dla mnie w mojej śmierci godzinie! Jezu konający, zakładzie miłosierdzia, złagódź gniew Boży w mojej śmierci godzinie" ${ }^{82}$. Coraz lepiej poznawała, jak bardzo każdy człowiek potrzebuje miłosierdzia Bożego w całym życiu, ale szczególnie w odchodzeniu z tego świata ${ }^{83}$. Od chwili, w której całkowicie zaufała miłosierdziu Bożemu, była gotowa na wezwanie Boga, „zdając się zupełnie na Jego najświętszą wolę, pełną miłosierdzia i litości" ${ }^{84}$.

Przekonana, że zawierzenie Bogu polega na pełnieniu Jego woli, czyniła wszystko, by zawsze i wszędzie realizować Boży plan na jej życie,

\footnotetext{
Por. Dz. 1616.

Por. Dz. 1574, 1565, 1639.

Por. Dz. 1265.

Dz. 813.

Dz. 1036.

Por. Dz. 1679.
} 
chociaż niejednokrotnie wiele ją to kosztowało ${ }^{85}$. Modliła się: „O Jezu, na krzyżu rozpięty, błagam Cię, udziel mi łaski, abym zawsze i wszędzie, we wszystkim wiernie spełniała najświętszą wolę Ojca Twego. A kiedy ta wola Boża wydawać mi się będzie ciężka i trudna do spełnienia, to wtenczas błagam Ciebie, Jezu, niechaj z ran Twoich spłynie mi siła i moc, a usta moje niech powtarzają: stań się wola Twoja, Panie" ${ }^{86}$. Boski Mistrz zapewniał ją, że największą chwałę oddaje Mu, kiedy poddaje się Jego woli. „Nie miałbym w tobie szczególniejszego upodobania, gdybyś nie żyła wolą Moją. [...] Cała Trójca Święta ma w tobie szczególne upodobanie, dlatego iż żyjesz wyłącznie wolą Bożą. Żadna ofiara nie idzie z tą w porównanie" 87 .

Dlatego napisała, że wola Boża jest dla niej wszystkim i jest jej obojętne, co Bóg z nią uczyni: „Każesz mi brać się do dzieła - zabieram się ze spokojem, choć wiem, że jestem do tego niezdolna; każesz mi czekać przez zastępców swoich - więc czekam z cierpliwością; napełniasz duszę moją zapałem - a nie dajesz możności czynu; pociągasz mnie za sobą $\mathrm{w}$ niebiosa - a pozostawiasz mnie na ziemi; wlewasz w duszę moją tęsknotę za Tobą - a kryjesz się przede mną. [...] O wolo Boża, tyś mi pokarmem i rozkoszą duszy" 88 .

Gdy w 1935 roku przed Dniem Zadusznym siostra Faustyna poszła na cmentarz, opisała następujący „dialog” ze zmarłymi: ,Jeżeli czego żądacie, duszyczki, chętnie wam zadośćuczynię". W odpowiedzi usłyszała: „Spełnij wolę Bożą. My o tyle jesteśmy szczęśliwe, o ile spełniłyśmy wolę Bożą"89.

Ufności i zawierzenia Bogu siostra Faustyna uczyła się całe życie, wiedziała bowiem, jak bardzo rani Serce Boże niedowierzanie ludzi. Gdy usłyszała od Chrystusa zapewnienie, że jak jest zjednoczona z Nim w życiu, tak też będzie zjednoczona w chwili śmierci, w jej sercu obudziła się tak wielka ufność w miłosierdzie Boże, że choćby miała na sumieniu grzechy całego świata, nie zwątpiłaby w Bożą dobroć, ale rzuciłaby się

\footnotetext{
85 Por. Dz. 372-374, 1574.

86 Dz. 1265.

87 Dz. 954-955; por. Dz. 518, 923.

88 Dz. 952.

89 Dz. 518; por. Dz. 515.
} 
do Jego stóp, „zdając się zupełnie na Jego świętą wolę, która jest miłosierdziem samym"90.

Często rozważała bolesną mękę Jezusa, w której dostrzegała największy przejaw Bożego miłosierdzia. Sam Jezus pouczał ją: „Jedna godzina rozważania Mojej bolesnej męki większą zasługę ma, aniżeli cały rok biczowania się aż do krwi; rozważanie Moich bolesnych ran jest dla ciebie z wielkim pożytkiem, a Mnie sprawia wielką radość" ${ }^{91}$. W styczniu 1938 roku zanotowała słowa Chrystusa: „Otworzyłem swe serce jako żywe źródło miłosierdzia, niech z niego czerpią wszystkie dusze życie, niech się zbliżą do tego morza miłosierdzia z wielką ufnością. Grzesznicy dostąpią usprawiedliwienia, a sprawiedliwi w dobrym utwierdzenia. Kto pokładał ufność w miłosierdziu Moim, napełnię duszę jego w godzinę śmierci swym Bożym pokojem ${ }^{92}$.

Warto podkreślić, że wszystkie nowe formy kultu Bożego Miłosierdzia objawione siostrze Faustynie zawierają obietnicę szczęśliwej śmierci ${ }^{93}$. Jezus Miłosierny zapewnia swoich czcicieli, że osłania ich przez całe życie, „jak czuła matka swe niemowlę, a w godzinę śmierci nie będę im Sędzią, ale miłosiernym Zbawicielem”. I dodaje, że w tej ostatniej godzinie nic człowiek nie ma na swą obronę oprócz Jego miłosierdzia ${ }^{94}$.

Siostra Faustyna w Wielki Piątek 1937 roku duchowo towarzyszyła Jezusowi w Jego męce i śmierci, a gdy wieczorem rozpłakała się, współczując Mu, wówczas usłyszała: „Nie płacz, już nie cierpię. A za wierność, z jaką towarzyszyłaś Mi w męce i śmierci - śmierć twoja będzie uroczysta i będę ci towarzyszył w tej ostatniej godzinie"95.

Chrystus pouczał ją, że łaski z Jego miłosierdzia czerpie się jednym naczyniem, a jest nim ufność, i im kto więcej zaufa, tym więcej otrzyma. „Wielką Mi są pociechą dusze o bezgranicznej ufności, bo w takie dusze przelewam wszystkie skarby swych łask. Cieszę się, że żądają wiele,

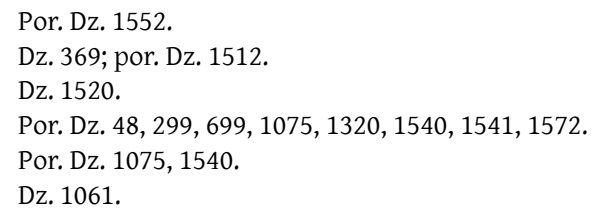


bo Moim pragnieniem jest dawać wiele, i to bardzo wiele"96. Uczennica Ukrzyżowanego Mistrza „kotwicę ufności” zapuściła głęboko w przepaść miłosierdzia Bożego i przez całe życie czerpała ze zdroju miłosierdzia, pomna na obietnicę Miłosiernego, że takiej duszy nie dosięgnie Boża sprawiedliwośćc ${ }^{97}$.

\section{3. Śmierć miłosnym hymnem wysławiającym miłosierdzie Boże}

Siostra Faustyna pod koniec życia doszła do takiego stanu ducha, że nie lękała się śmierci, ale z utęsknieniem jej wyczekiwała, jako pełnego miłości spotkania z Bogiem miłosierdzia. We wszystkich okolicznościach życia uwielbiała miłosierdzie Boże i uważała to za jej jedyne zadanie w życiu, śmierci i w wieczności. „Żaden umysł nie zgłębi tajemnic miłosierdzia Twego, o Boże, ani anioł, ani człowiek. Zdumiewają się aniołowie nad tajemnicą miłosierdzia Bożego, ale Go pojąć nie mogą. Wszystko, co wyszło z rąk Stwórcy, zamknięte jest w tajemnicy niepojętej, to jest we wnętrznościach Jego miłosierdzia. Gdy to rozważam, duch mój ustaje, w radości serce się rozpływa. O Jezu, przez Twoje najlitościwsze Serce jak przez kryształ przeszły do nas promienie miłosierdzia Bożego"98.

W kwietniu 1938 roku siostra Faustyna poczuła się wyłączną własnością Boga i w mistycznym widzeniu ujrzała chwałę miłosierdzia Bożego oraz wielkie tłumy ludzi, którzy wysławiali dobroć Jego ${ }^{99}$.

Znamienne jest jej wyznanie z początków życia zakonnego, gdy przeżywała oschłości ducha, dręczona była pokusami przeciw wierze i walczyła z myślami bluźnierczymi, i gdy wydawało jej się, że jest potępiona, wówczas weszła do kaplicy i zawołała: „Czyń ze mną, o Jezu, co Ci się podoba. Ja Ciebie wszędzie uwielbiać będę"100.

Świadoma swej nicości, pragnęła kochać Jezusa miłością jedyną i niepowtarzalną i pomimo „swej nędzy” miała nadzieję śpiewać „pieśń chwały wiecznie". Zachęcała przy tym, by nikt nie wątpił, bo dopóki

96 Dz. 1578.

97 Por. Dz. 1075, 1513.

98 Dz. 1553.

99 Dz. 1681.

100 Por. Dz. 77, 78. 
żyje - każdy może stać wielkim świętym, bo wielka jest moc łaski Bożej. Trzeba tylko zaufać Bogu i nie stawiać oporu działaniu Bożemu ${ }^{101}$.

Największą radość siostra Faustyna przeżywała wówczas, gdy widziała, że Bóg jest kochany, że rozbrzmiewają cześć i chwała miłosierdzia Bożego, o czym świadczy następujący zapis: „O Chryste, do ostatniego momentu życia nie przestanę wysławiać Twojej dobroci i miłosierdzia. Każdą kroplą krwi, każdym uderzeniem serca wysławiam Twoje miłosierdzie. Pragnę się cała zamienić w hymn uwielbienia Ciebie. Kiedy już będę na łożu śmierci, niechaj ostatnie uderzenie serca mojego będzie miłosnym hymnem, wysławiającym niezgłębione miłosierdzie Twoje"102.

W lutym 1938 roku, na kilka miesięcy przed śmiercią, wyczekując, kiedy Bóg ją wezwie, napisała, że gdy w zjednoczeniu ze swym Zbawicielem, pełna ufności w niezgłębione miłosierdzie Boże odda swoją duszę w ręce Ojca niebieskiego, wówczas „w niebie zanuci pierwszy hymn miłosierdziu Bożemu”"103. „Miłosierdzie Twoje będzie mi wszystkim w tej ostatniej godzinie - jakoś mi sam przyobiecał"104.

\section{Miłość potężniejsza niż śmierć}

Niespełna półtora roku przed śmiercią siostra Faustyna zanotowała, że dopóki żyjemy, miłość Boża w nas wzrasta i aż do śmierci powinniśmy się starać o tę Bożą miłość w duszy. Ci, którzy żyją w miłości, odznaczają się wyjątkowym światłem w poznawaniu rzeczy Bożych. Sama święta doświadczała wyjątkowej miłości Bożej, „zanurzona w oceanie miłości”, wpadała w „omdlenie i zatracała się w Bogu” ${ }^{105}$. Wiedziała, że wielka miłość „,rzeczy małe umie zamieniać na rzeczy wielkie i tylko miłość nadaje czynom naszym wartość", i tylko czysta miłość sprawia, że „ogień cierpień mniej będzie miał w nas do trawienia, a cierpienie przestanie być cierpieniem - stanie się nam rozkoszą". Siostra Faustyna

\footnotetext{
101 Por. Dz. 283.

102 Dz. 1708.

103 Por. Dz. 1582.

104 Dz. 1574.

105 Por. Dz. 513, 1191.
} 
doszła do takiego stanu ducha, że nigdy nie była tak szczęśliwa, jak wówczas, kiedy cierpiała dla Jezusa, którego kochała „każdym drgnieniem serca"106.

„Na ołtarzu miłości - czytamy w Dzienniczku - będzie płonąć czysta ofiara woli mojej; aby ofiara moja była doskonała, łączę się ściśle z ofiarą Jezusa na krzyżu". I dodała, że kiedy pod wpływem wielkich cierpień jej siły fizyczne i duchowe zmniejszać się będą, wtenczas ukryje się głęboko w otwartej ranie Serca Jezusowego ${ }^{107}$. Wiedziała, że miłość zniesie wszystko, miłość przetrwa śmierć, miłość nie zna bojaźni, „przechodzi przez wszystkie chóry anielskie, które przed Jego tronem trzymają straż", miłość dosięga Boga i tonie w Nim jako w jedynym skarbie swoim. „Cherubin z mieczem ognistym, który strzeże raju, nie ma władzy nad nią. O czysta miłości Boża, jakżeś wielka i nieporównana"108.

Pouczona przez swojego Mistrza, wiedziała, że jedyną rzeczą, która ma w oczach Boga nieskończoną wartość, ,jest miłość Boża, miłość, miłość i jeszcze raz miłość - i z jednym aktem czystej miłości Bożej nie może iść nic w porównanie. O, jakimi niepojętymi względami Bóg darzy duszę, która Go szczerze miłuje” ${ }^{109}$. Innym razem usłyszała: „O, gdybyś wiedziała, jak wielką zasługę i nagrodę ma jeden akt czystej miłości ku Mnie, umarłabyś z radości. Mówię to dlatego, abyś się ustawicznie łączyła ze Mną przez miłość, bo to jest cel życia duszy twojej; akt ten polega na akcie woli" ${ }^{110}$.

Można powiedzieć, że całe życie siostry Faustyny było jednym wielkim aktem miłości; czuła, że pali się w niej „żar”, i nie rozumiała „innego życia prócz ofiary, która płynie z czystej miłości; była przekonana, że śmierć niczego, co dobre, nie niszczy, nie pokona także miłości, którą nazywała królową ${ }^{111}$.

\footnotetext{
106 Por. Dz. 303.

107 Por. Dz. 957.

108 Por. Dz. 46, 781.

109 Por. Dz. 778.

110 Dz. 576.

111 Por. Dz. 694, 784, 780.
} 


\section{1. Śmierć Bożym posłańcem}

W styczniu 1938 roku siostra Faustyna opisała stan swojego samopoczucia - zauważyła, że kiedy w chorobie Pan Bóg nie daje ani śmierci, ani zdrowia i taki stan trwa latami, „,wówczas zaczyna się pasmo cichego męczeństwa". A gdy jej zdrowie się poprawiło, stwierdziła, że Jezus przyprowadza ją „od bram śmierci do życia”. Napisała wtedy, że tak bardzo pragnęła śmierci, że chyba nigdy nie będzie mieć tak wielkiej tęsknoty za Bogiem, a gdy poznała piękno nieba, „brzydką” wydawała jej się ziemia. I dodawała: „O wolo Boża, tyś moim pokarmem”112.

W tej tęsknocie i cierpieniu błagała Stwórcę, by zabrał ją do nieba; dziwiła się, że Bóg nie „pozwala śmierci zbliżyć się do niej”. Umiera i umiera z tęsknoty za Bogiem, a umrzeć nie może. W tym utęsknieniu wołała: „Śmierci, gdzie jesteś? Pociągasz mnie w otchłań Bóstwa swego i zasłaniasz się ciemnością. Cała istota moja jest zanurzona w Tobie, jednak ja pragnę Cię oglądać twarzą w twarz. Kiedyż to nastąpi dla mnie. [...] O śmierci, posłańcu Boży, kiedy mi zwiastujesz tę upragnioną chwilę, przez którą się zjednoczę na wieki z Bogiem moim?"113.

\subsection{Niebo - szczęście, jakie nas czeka}

U siostry Faustyny znajduje się wiele fragmentów ukazujących majestat i piękno nieba oraz szczęście, jakie czeka człowieka, a które ma swoje źródło w Bogu. „Dziś miłość Boża przenosi mnie w zaświaty - zanotowała. Jestem pogrążona w miłości, kocham i czuję, że jestem kochana, i całą świadomością to przeżywam. Tonie moja dusza w Panu, poznając wielki majestat Boży i maleńkość swoją, lecz przez to poznanie zwiększa się szczęście moje. Ta świadomość jest tak żywa w duszy, tak potężna, a zarazem tak słodka"114.

Pół roku przed śmiercią siostra Faustyna napisała swego rodzaju hymn na cześć Miłości, do której zmierzała: „O Rano Miłosierdzia, Serce Jezusa,

\footnotetext{
112 Por. Dz. 897, 899, 1509.

113 Por. Dz. 841, 952, 1573.

114 Dz. 1500.
} 
ukryj mnie w swej głębi jako jedną kropelkę krwi własnej i nie wypuszczaj mnie z niego na wieki. Zamknij mnie w swych głębiach i naucz mnie sam kochać Ciebie. Miłości wieczna, urabiaj sam moją duszę, aby była zdolna do wzajemnej miłości Ciebie. O żywa Miłości, uczyń mnie zdolną do wiecznego kochania Ciebie. Chcę wiecznie odpowiadać wzajemnością na Twoją miłość. o Chryste, jedno spojrzenie Twoje droższe mi jest niżeli światów tysiące, niżeli niebo całe. Ty możesz, Panie, uczynić mą duszę tak, aby umiała zrozumieć Ciebie w całej pełni, jakim jesteś"115.

Była przekonana, że jej ojczyzna jest w niebie, gdzie króluje Bóg, a śmierć to powrót „do Ojca swego w niebo wiekuiste, z ziemi wygnania” ${ }^{116}$. W listopadzie 1936 roku „była w niebie” i oglądała te „niepojęte piękności i szczęście”, jakie nas czekają po śmierci. „Widziałam, jak wszystkie stworzenia oddają cześć i chwałę nieustannie Bogu; widziałam, jak wielkie jest szczęście w Bogu, które się rozlewa na wszystkie stworzenia, uszczęśliwiając je, i wraca do Źródła wszelka chwała i cześć z uszczęśliwienia, i wchodzą w głębie Boże, kontemplują życie wewnętrzne Boga: Ojca, Syna i Ducha Świętego, którego nigdy ani pojmą, ani zgłębią. To Źródło szczęścia jest niezmienne w istocie swojej, lecz zawsze nowe, tryskające uszczęśliwieniem wszelkiego stworzenia. Rozumiem teraz św. Pawła, który powiedział: Ani oko nie widziało, ani ucho nie słyszało, ani weszło w serce człowieka, co Bóg nagotował tym, którzy Go miłują"117.

W lutym 1937 roku opisała kolejne doświadczenie, jakie dane było jej przeżyć w kontekście poznania tajemnicy i majestatu Boga. „O, czy moge choć trochę wyrazić, co dusza moja przeżywa przy Sercu niepojętego majestatu. Nie umiem tego wypowiedzieć, [...] zdawało mi się, że wróciłam z życia prawdziwego do śmierci. [...] Wiem tylko to, że konam z tęsknoty za Bogiem" $" 118$.

Siostra Faustyna była przekonana, że choć niebiosa są wielkie i wspaniałe, to jednak niczym byłyby bez Boga. Już w lutym 1937 roku, gdy

\footnotetext{
115 Dz. 1631.

116 Por. Dz. 1589, 1653.

117 Dz. 777.

118 DZ. 970.
} 
modliła się przed Najświętszym Sakramentem, Jezus powiedział, że wszystko, co istnieje, należy do niej. Wówczas odpowiedziała Panu: „Niczego nie żąda serce moje, tylko Ciebie jednego, o Skarbie serca mojego; za wszystkie dary, które mi dajesz, dziękuję Ci, o Panie, ale ja żądam tylko Serca Twego. Choć wielkie są niebiosa, niczym są dla mnie bez Ciebie; Ty dobrze wiesz, o Jezu, że ustawicznie omdlewam z tęsknoty za Tobą"119. Jezus był dla niej jedyną miłością; całe niebo od Niego się zapala i napełnia miłością. „A więc pożąda Cię dusza moja, jak żąda kwiat słońca" ${ }^{20}$.

W kwietniu 1938 roku, pięć miesięcy przed śmiercią, świadoma, że jej życie „ma się ku schyłkowi”, że idzie „na wieczne gody, w wiekuiste niebo, w niepojęte przestworza", wyznała, że nie pragnie odpocznienia ani nagrody, pociąga ją „w niebo czysta miłość Boża”. „Już idę na spotkanie się z Tobą, wieczna Miłości, sercem stęsknionym, które pragnie Ciebie. Czuję, że Twa miłość czysta, Boże, w mym sercu gości, i czuję swe wieczne przeznaczenie w niebie. Już idę do Ojca swego w niebo wiekuiste, z ziemi wygnania, z tej łez doliny. [...] Już idę, o mój Oblubieńcze, by ujrzeć Twą chwałę, która już teraz napełnia mą duszę radością, gdzie w adoracji Ciebie pogrąża się niebo całe"121.

Siostra Faustyna, rozpalona żarem miłości Bożej, z ufnością w nieskończone miłosierdzie Boże, odeszła do domu Ojca niebieskiego 5 października 1938 roku, przeżywszy zaledwie 33 lata.

\subsection{Siostra Faustyna uchyla „zasłony nieba”}

Dwa lata przed śmiercią siostra Faustyna po komunii świętej usłyszała zachętę Chrystusa, by czuwała, bo On przyjdzie niepostrzeżenie (por. Mk 13, 35). Wówczas z ufnością wyznała, że jest On zawsze miłosiernym Zbawicielem i nie zmieni się dla niej w godzinę śmierci. Jeżeli przez całe życie okazuje jej tyle szczególnej miłości i tak poufale łączy się z nią, spodziewa się jeszcze więcej po śmierci. Niebiosa mogą się odmienić, ale

\footnotetext{
119 Dz. 969.

120 Dz. 1808.

121 Dz. 1653.
} 
On, Pan, zawsze będzie ten sam na wieki: Ojciec nieskończonego miłosierdzia, a ona z utęsknieniem czeka na Jego przyjście ${ }^{122}$. Pamiętała słowa Zbawiciela: „Prędzej niebo i ziemia obróciłyby się w nicość, aniżeliby duszy ufającej nie ogarnęło miłosierdzie Moje"123.

Zdawała sobie sprawę ze stanu swojego zdrowia; widziała, że pomimo wysiłków lekarzy słabły jej siły i uchodziło z niej życie. Cieszyła się jednak z tego wezwania Bożego, bo wiedziała, że z chwilą śmierci rozpocznie się jej posłannictwo. Czuła, że jej uwielbienie miłe jest Bogu, choć jest „nicością”, dlatego „w wiekuistym szczęściu nie zapomni o ludziach na ziemi, ale wypraszać będzie miłosierdzie Boże wszystkim" ${ }^{124}$. Napisała: „Czuję dobrze, że nie kończy się posłannictwo moje ze śmiercią, ale się zacznie. O dusze wątpiące, uchylę wam zasłony nieba, aby was przekonać o dobroci Boga, abyście już więcej nie raniły niedowierzaniem najsłodszego Serca Jezusa. Bóg jest Miłością i Miłosierdziem"125.

Pod koniec życia siostra Faustyna otrzymywała listy od współsióstr, które pisały, że z jednej strony smucą się z powodu jej choroby, a zarazem cieszą się, bo gdy Pan Jezus zabierze ją, to będzie się za nie modliła, bo ona „wiele u Pana może”. Polecały jej różne sprawy, przeczuwając, że będzie mogła im to uprosić u Pana Jezusa ${ }^{126}$.

Odchodząc z tego świata, św. siostra Faustyna napisała: „Uchylę zasłony nieba, aby o dobroci Twojej nie wątpiła ziemia"127. Po 80 latach od jej śmierci rozwijający się na całym świecie kult Bożego miłosierdzia pokazuje, jak prorocze były to słowa.

\section{Zakończenie}

Dzienniczek św. siostry Faustyny zawiera cenne wskazówki dotyczące sensu życia ludzkiego i umierania. Przedłużająca się choroba siostry

\footnotetext{
122 Por. Dz. 854.

123 Dz. 1777.

124 Por. Dz. 1653, 1729.

125 Dz. 281.

126 Por. Dz. 1614, 1673.

127 Dz. 281; por. Dz. 483.
} 
Faustyny i różnorakie cierpienia stały się dla niej czasem duchowego dojrzewania i zjednoczenia z Bogiem. Często stawała w obliczu śmierci, w obliczu wieczności, a każdy dzień jej życia był powolnym umieraniem. Dlatego przygotowywała się do śmierci i coraz bardziej uświadamiała sobie fakt, że „śmierć niczego, co dobre, nie niszczy [i] żaden czyn w Bogu podjęty nie zginie"128.

Siostra Faustyna żyła na co dzień nie tylko perspektywą śmierci, lecz także życia wiecznego. Przeżywane walki duchowe i wewnętrzne zmagania łagodził w niej sam Chrystus, zachęcając do zawierzenia Jego miłosiernej miłości, której bezkresną głębię dał jej poznać w objawieniu orędzia o Bożym miłosierdziu.

Apostołka Bożego miłosierdzia była przekonana, że śmierć fizyczna jest przejściem do życia prawdziwego i że dopiero z chwilą śmierci zacznie się dla niej prawdziwe życie i prawdziwe szczęście. Dzień śmierci nazywała dniem upragnionym, pięknym, jasnym. Tego dnia oczekiwała z utęsknieniem. Nie przerażał jej realizm umierania, bo zaufała całkowicie dobroci Boga, dlatego z upragnieniem czekała na śmierć, jako na spotkanie z Miłością Miłosierną, ze Zbawicielem, którego umiłowała całą duszą.

128 Por. Dz. 694, 1435. 


\section{Summary}

\section{Miłość większa niż śmierć w doświadczeniu mistycznym św. siostry Faustyny}

Obchody 80-lecia śmierci św. siostry Faustyny Kowalskiej, polskiej świętej, inspirują do pochylenia się nad jej duchową spuścizną, jaką pozostawiła w Dzienniczku, pisanym przez ostatnie cztery lata swego życia. Jawi się nam jako apostołka Bożego miłosierdzia, inspiratorka ruchu apostołów Bożego miłosierdzia, obejmującego wszystkie kontynenty, mistyczka i mistrzyni życia duchowego. Jej doświadczenie Boga miłosierdzia daje nowe spojrzenie także na człowieka w kontekście jego umierania, śmierci i wieczności. Siostra Faustyna pozostaje ciągle wiarygodnym świadkiem, a zarazem niedościgłym wzorem zawierzenia Bogu, który nieustannie pochyla się nad człowiekiem. Jej Dzienniczek to dobra szkoła uwielbienia Boga w jego miłosierdziu i przygotowania się do spotkania z Nim w godzinie śmierci.

Słowa kluczowe: św. siostra Faustyna, Miłosierdzie Boże, zawierzenie, ufność, śmierć

\section{Love Greater than Death in St. Faustina's Mistical Experience}

Celebration of the 80th anniversary of the death of saint sister Faustina Kowalska, the Polish saint, inspire us to take a closer look at her spiritual heritage she left in the Diary, written during the last four years of her life. She appears to us as an apostle of the Divine mercy, as the inspirer of the movement of the apostles of Divine mercy, embracing all continents, as the mystic and the master of spiritual life.

Her experience of God of mercy gives a new look also to a man in the context of his dying, death and eternity. Sister Faustina is still a reliable witness, and at the same time an unattainable model of entrusting to God, who constantly bends over a man. Her Diary appears as a good school of praising God in His mercy and preparing to meet Him at the hour of death.

Keywords: saint sister Faustina, Divine mercy, entrustment, trust, death

\section{Bibliografia}

Andrasz J., Życiorys świętej Faustyny, Kraków 2015.

Benedykt XVI, O przeżyciach w Polsce, Audiencja środowa 31.05.2006, http:// info.wiara.pl/doc/159412.Audiencja-srodowa-Benedykt-o-przezyciach-w-Polsce/3 (06.01.2018).

Dziwisz S., Homilia Kard. Stanisława Dziwisza, w: Błogosławieni miłosierni, albowiem oni miłosierdzia dostapia. Papież Franciszek w Polsce. 27-31 lipca 2016 r., Marki 2016, s. 13-14.

Flynn V., 7 tajemnic Eucharystii, tłum. P. Kopycki, Radom 2011. 
Franciszek, Bulla Misericordiae vultus.

Franciszek, Miłosierdzie to imię Boga. Rozmowa z Andreą Torniellim, przekł. J. Ganobis, Kraków 2016.

Jan Paweł II, Dar Boży dla naszych czasów. Homilia w czasie Mszy Świętej kanonizacyjnej bt. s. Faustyny Kowalskiej w dniu 30 kwietnia 2000 r., „L'Osservatore Romano” wyd. pol. nr 6 (2000), s. 25-26.

Jan Paweł II, Encyklika Dives in Misericordia.

Jan Paweł II, Pamięć i tożsamość. Rozmowy na przełomie tysiącleci, Kraków 2005.

Jan Paweł II, List apostolski 0 tajemnicy i kulcie Eucharystii.

Jan Paweł II, Adhortacja apostolska Reconciliatio et paenitentia.

Jan Paweł II, List do moich Braci i Sióstr - ludzi w podeszłym wieku.

Listy świętej Siostry Faustyny, oprac. B. Piekut, Kraków 2005.

Miczyński J., Fundament duchowości i charyzmat Zgromadzenia Sióstr Matki Bożej Miłosierdzia, Lublin 2016.

Pismo Święte Starego i Nowego Testamentu w przekładzie zjęzyków oryginalnych, oprac. zespół biblistów polskich z inicjatywy Benedyktynów Tynieckich (Biblia Tysiąclecia), Poznań 2005.

Rebeta W., Misterium cierpienia św. Faustyny, Lublin, 2014.

Różycki I., Nabożeństwo do Miłosierdzia Bożego. Studium teologiczne Dzienniczka bł. s. Faustyny Kowalskiej na temat Nabożeństwa, Kraków 1999.

Siepak E., Nowe „Zgromadzenie” Siostry Faustyny. Apostolski Ruch Bożego Miłosierdzia, Kraków 2002.

Sławiński H., Ambiwalentne postawy człowieka wobec cierpienia, ,Studia Włocławskie” 10 (2007), s. 213-220.

Św. Siostra Faustyna Kowalska, Dzienniczek. Miłosierdzie Boże w duszy mojej, Kraków 2014.

Urbański S., Mistyczny świat ducha [Kanonizacja s. Faustyny Kowalskiej], Warszawa 2000.

Wejman H., Kontemplować Boga w tajemnicy Jego miłosierdzia, Kraków 2006.

Wspomnienia o świętej Faustynie Kowalskiej ze Zgromadzenia Matki Bożej Miłosierdzia, oprac. E. Siepak, Kraków 2013. 